D. de M. Bento, R.L. Ferreira, X. Prous, M. Souza-Silva, B.C. Bellini, and A. Vasconcellos - Seasonal variations in cave invertebrate communities in the semiarid Caatinga, Brazil. Journal of Cave and Karst Studies, v. 78, no. 2, p. 61-71. DOI: 10.4311/2015LSC0111

\title{
SEASONAL VARIATIONS IN CAVE INVERTEBRATE COMMUNITIES IN THE SEMIARID CAATINGA, BRAZIL
}

\author{
Diego de M. Bento ${ }^{*}$, Rodrigo L. Ferreira², Xavier Prous², Marconi Souza-Silva², \\ Bruno Cavalcante Bellini ${ }^{3}$, and Alexandre Vasconcellos ${ }^{4}$
}

\begin{abstract}
The Brazilian semiarid region has a clear distinction between the dry season, which can last up to nine months, and the rainy season. Caves are connected to different extents to surface ecosystems, although they are idealized as stable environments due to their isolation. Furthermore, little is known about the effects of wet and dry seasonal variations on underground biological assemblages. Invertebrate communities were analyzed during dry and rainy seasons in 24 caves in the semiarid region of northeastern Brazil. We also investigated whether the environmental stability of caves attenuates the effects of seasonality in this particular region. Morphospecies richness and abundance and the diversity indexes of caves were significantly higher during the rainy season. In addition, more stable caves showed less variation in the community composition between seasons. Our data point to a clear influence of the surface ecosystems on the caves in Caatinga. However, the intensity of this influence apparently depends on the environmental stability of the cave, and the most stable caves present smaller changes in the structure of their invertebrate communities during different seasons.
\end{abstract}

\section{INTRODUCTION}

The underground environment has distinct features in comparison to adjacent surface ecosystems: a permanent lack of light, except in areas near the entrances, and a higher tendency toward stable environmental conditions such as temperature and moisture (Culver, 1982). The size of the oscillation of these climatic parameters will depend substantially on the morphological complexity of the cave and on the amplitude of climatic variations on the surface (Culver and White, 2005).

The permanent absence of light inside caves prevents the existence of photoautotrophic organisms. Therefore, food sources available for the resident fauna usually have allochthonous origin (Schneider et al., 2011; Souza-Silva et al., 2011a). Such resources are imported from the external environments continuously or temporarily by physical and biological agents (Culver, 1982; Howarth, 1983; Ferreira and Martins, 1999). Hence, cave ecosystems are generally, to a greater or lesser extent, connected to surface ecosystems, whose environmental variations affect the communities of cave invertebrates (Culver, 1982; Culver and White, 2005; Souza-Silva et al., 2011a; Simões et al., 2015). The general features of numbers, positions, distribution, and extents of the entrances and their relation with the length of caves are factors that can act directly on the maintenance of microclimate in underground environments (Ferreira, 2004; Simões et al., 2015).

Caves located in semiarid ecosystems are generally subject to seasonal variations in the external environment with a clear alternation between dry and rainy seasons. The structure of cave communities may suffer alterations due to climate changes on the surface, given that the resource availability may increase during the rainy season for some weeks or months (Culver and White, 2005; Souza-Silva et al., 2011a). The availability may also decrease because of intense leaching that might follow the organic resources importation (Souza-Silva et al., 2007; Souza-Silva et al., 2011a).

The Brazilian semiarid region has a relatively predictable seasonality, with a dry season that may last for more than nine months (Sampaio, 1995). The effects of climatic variables in the ecoregion of Caatinga on several invertebrate taxa in epigean ecosystems have already been investigated. Some of the sampled taxa were Apoidea (Aguiar and Martins, 1997), Sphingidae (Gusmão and Creão-Duarte, 2004), Buprestidae (Iannuzzi et al., 2006), Scarabeidae (Hernández, 2007), Scorpiones (Araújo et al., 2010a), and ants (Medeiros et al., 2012), besides some studies on larger groups like Hexapoda (Vasconcellos et al., 2010) and soil macroarthopods (Araújo et al., 2010b). The vast majority of these studies have shown a positive relation between population size and rainfall.

Other studies of seasonality in caves are scarce and restricted to a few groups such as mites in Belgium

\footnotetext{
* Corresponding author: diego.bento@icmbio.gov.br

${ }^{1}$ Centro Nacional de Pesquisa e Conservação de Cavernas, Base Avançada Compartilhada no Rio Grande Do Norte, Instituto Chico Mendes de Conservação da Biodiversidade. 59015-350 Natal, Rio Grande do Norte, Brasil.

${ }^{2}$ Centro de Estudos em Biologia Subterrânea, Setor de Zoologia Geral, Departamento de Biologia (DBI), Universidade Federal de Lavras (UFLA), Minas Gerais, CEP: 37200-000, Brasil.

${ }^{3}$ Departamento de Botânica, Ecologia e Zoologia, Centro de Biociências, Universidade Federal do Rio Grande do Norte, CEP 59072-970, Natal, Rio Grande do Norte, Brazil.

${ }^{4}$ Laboratório de Termitologia, Departamento de Sistemática e Ecologia, Universidade Federal da Paraíba, 58051-900, João Pessoa, Paraíba, Brazil.
} 
(Ducarme et al., 2004), crickets in North America (Lavoie et al., 2007), and even a single species of spider in southern Brazil (Ferreira et al., 2005). In caves at Caatinga, most other studies were focused solely on the characterization of invertebrate communities, without regard to season (Trajano, 1987; Ferreira and Martins, 1998; Ferreira et al., 2010).

The present study aimed to evaluate changes in the structure of invertebrate communities between the dry and rainy seasons in limestone caves from five municipalities in the semiarid region of Brazil. In addition, we also investigated if the environmental stability of these caves can mitigate the effects of seasonal variations on invertebrate communities. In this context, due to the strong seasonality on the surface and the connection between epigean and hypogean environments, we expected changes in the structure of the cave invertebrate community between dry and rainy seasons, and that caves with greater environmental stability would have less fluctuation in the composition of the invertebrate community throughout the year.

\section{Material And Methods}

The study was conducted in 24 caves in the municipalities of Baraúna, Felipe Guerra, Governador Dix-Sept Rosado, Apodi, and Mossoró, Rio Grande do Norte state, northeastern Brazil (Figure 1; Table 1). These caves are embedded in the limestones of the Jandaíra Formation, which is the most extensive area of carbonate outcrops of Phanerozoic age in Brazil. Deposited between the MesoTuronian and Eocampanian, the rocks of Jandaíra Formation are a carbonate ramp that crops out in almost all the onshore portion of the Potiguar Basin. This carbonate ramp was submitted, during and after deposition, to various episodes of uplift that led to a subaerial exposure and erosion, resulting in intense epigenetic karstification (Bezerra et al., 2007).

Most caves in the area occur as clusters in limestone outcrops locally called lajedos. The sampled caves were randomly selected according to georeferenced data from all the caves of the area in order to cover all these clusters.

The climate is predominantly $\mathrm{BSw}^{\prime} \mathrm{h}^{\prime}$ according to the Köppen climate classification, characterized as a hot and semiarid climate, in which the rainy season is delayed to the autumn (Kottek et al., 2006). The average long-period annual rainfall is about $670 \mathrm{~mm}$, the potential evaporation is over $1,760 \mathrm{~mm}$, and there is a water deficit of $1,000 \mathrm{~mm}$ during nine months. The rainfall is irregular and occurs in the period between February and July, most frequently between March and June. The relative humidity is variable, usually between 59 and $76 \%$, and the annual average temperature is around $28{ }^{\circ} \mathrm{C}$ (IDEMA, 2005).

The determination of sampling dates was based on analysis of data from 1999 to 2009 about the water balance (rainfall and water surplus/drought) of the municipalities of the study area (INPE, 2010). Two sampling visits were conducted on each cave between December 2009 and August 2010, one at the end of the dry season and other at the end of the rainy season, with a six-month interval between visits.

We carried out the sampling by visually searching across all the same accessible parts of each cave during both events, prioritizing organic matter such as debris, carcasses, and guano and microhabitats such as humid soil, cracks, speleothems, and spaces under rocks. Manual collections were made with the aid of tweezers, brushes, and entomological nets (Souza-Silva et al., 2011b). Invertebrates were collected from water bodies with the aid of forceps, hand nets, and creels, in accordance with Ferreira et al. (2010).

The collection team was always composed of the same four biologists with experience in caving and manual collection of invertebrates, as recommended by Weinstein and Slaney (1995). This methodology is effective for collections and reduces the impact generated by other kinds of sampling, such as the installation of pitfall traps, which are notorious for causing population disturbances in caves (Weinstein and Slaney, 1995; Sharratt et al., 2000). To ensure that the sampling was as standardized as possible, the sampling time was approximately one hour per $50 \mathrm{~m}^{2}$ cave area for each biologist.

All invertebrates were identified to the lowest possible taxonomic level and grouped in morphospecies for all statistical analysis (Oliver and Beattie, 1996a; Derraik et al., 2002; Ward and Stanley, 2004; Derraik et al., 2010; Souza-Silva et al. 2011b). Oliver and Beattie (1996a) showed that morphospecies identified by non-specialists can provide estimates of richness and turnover consistent with those generated using species identified by taxonomic specialists. The use of morphospecies or corrected morphospecies inventories in the analyses generally provides results concordant with conventional species inventories (Oliver and Beattie, 1996b).

All the invertebrate morphospecies found on each cave had some specimens collected. The individuals observed during the collections were counted and plotted on schematic maps of each cave according to the methodology proposed by Ferreira (2004). All caves in this study were mapped using a standardized mapping methodology with degree of precision 4D-BCRA (Day, 2002), with additional information related to the area of the cave and the number and area of the entrances.

The general abundance of each morphospecies was acquired through the recording of individuals on each schematic map, thus generating information regarding morphospecies richness, abundance, and spatial distribution of each population. Taxa of small size with large populations concentrated in accumulations of organic matter, such as Collembola in guano deposits, had their abundance estimated from the count of individuals in a square decimeter, extrapolated to the area occupied by the nutrient source. The calculation of diversity was made using the Shannon index (Magurran, 1988). 


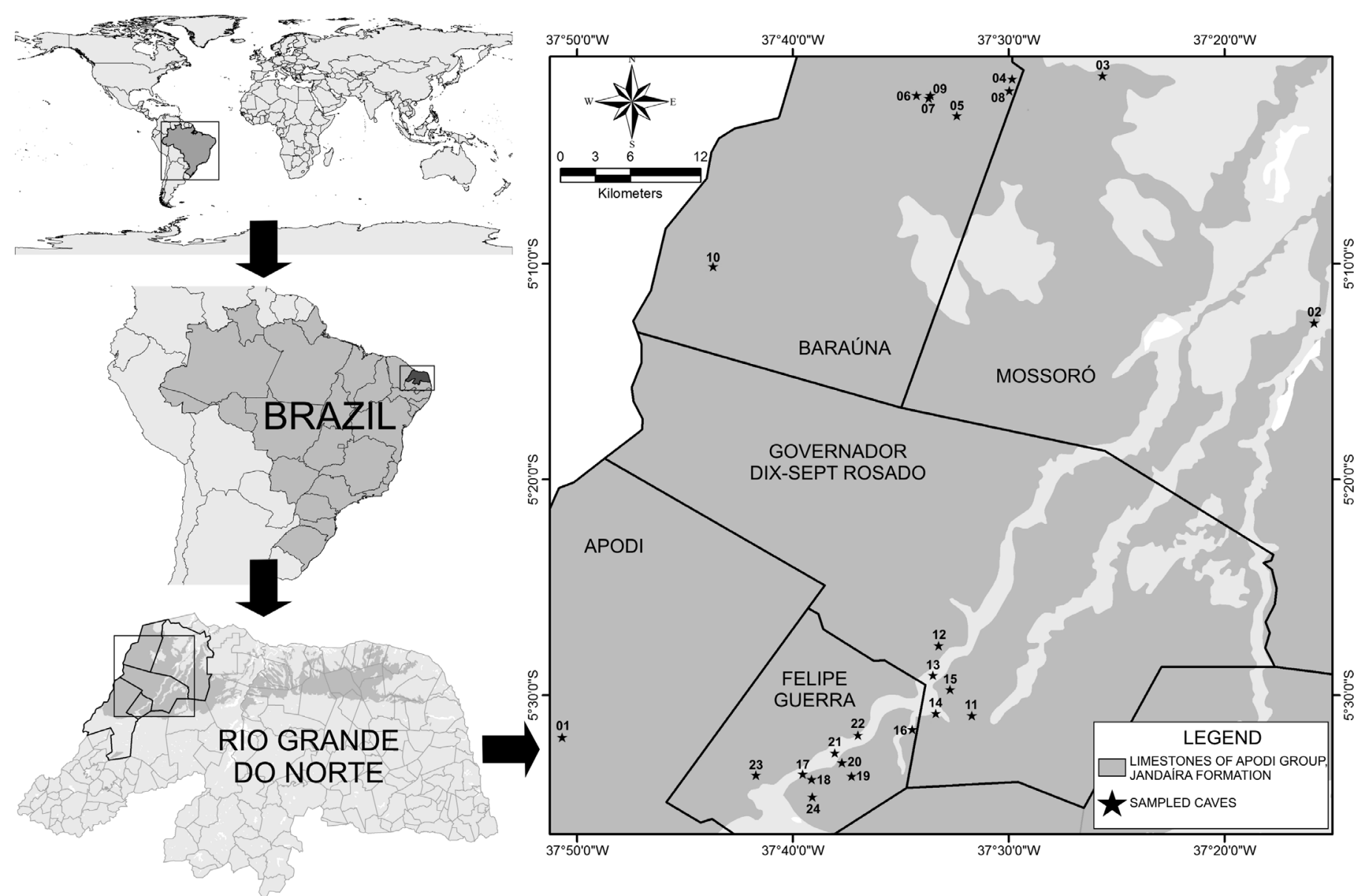

Figure 1. Map with the location of the study area and sampled caves. The numbered caves are identified in Table 1.

The environmental stability of each cavity was determined using the Environmental Stability Index (ESI) (Ferreira, 2004), modified to use the area of the cave (in square meters) instead of its linear extent. The index considers the isolation of the cave atmosphere and the external one through a mathematical ratio between the total area of the cave, the area of entrances, and the distance among them according to the following formulas:

For caves having just one entrance

$$
E S I=\ln \left(\frac{A T}{A E}\right)
$$

where $E S I$ is the Environmental Stability Index, $A T$ is the total area of each cave $\left(\mathrm{m}^{2}\right)$, and $A E$ is the area of the cave entrance $\left(\mathrm{m}^{2}\right)$.

For caves having more than one entrance

$$
E S I=\ln \left[\frac{\left(A T^{2} / \Sigma A E\right)}{N E D E}\right],
$$

where $E S I$ is the Environmental Stability Index, $A T$ is the total area of the cavity $\left(\mathrm{m}^{2}\right), \Sigma A E$ is the total area of the cave's entrances $\left(\mathrm{m}^{2}\right), N E$ is the number of entrances, and $D E$ is the average distance between entrances, taking the largest of them as reference.

We used the Levene test to verify the homogeneity of variance between seasons of each of the parameters morphospecies richness, abundance, and diversity index. The variables that were not normally distributed (morphospecies richness and abundance of individuals) were normalized with natural log. Then differences between the community parameters' averages for rainy and dry seasons were verified by t-test.

Finally, to verify the similarity between invertebrate communities in the same cave, but from different seasons, a matrix of similarity was built based on presence and absence data using the Bray-Curtis coefficient through the software Primer-5 (Clarke and Warwick, 2001). Subsequently, a Pearson correlation test was applied on the similarity values (dry/rainy) and ESI values of the sampled caves to check if the more stable caves have a greater similarity between seasons and showed a lower influence of the epigean ecosystems.

Journal of Cave and Karst Studies, August 2016 • 63 


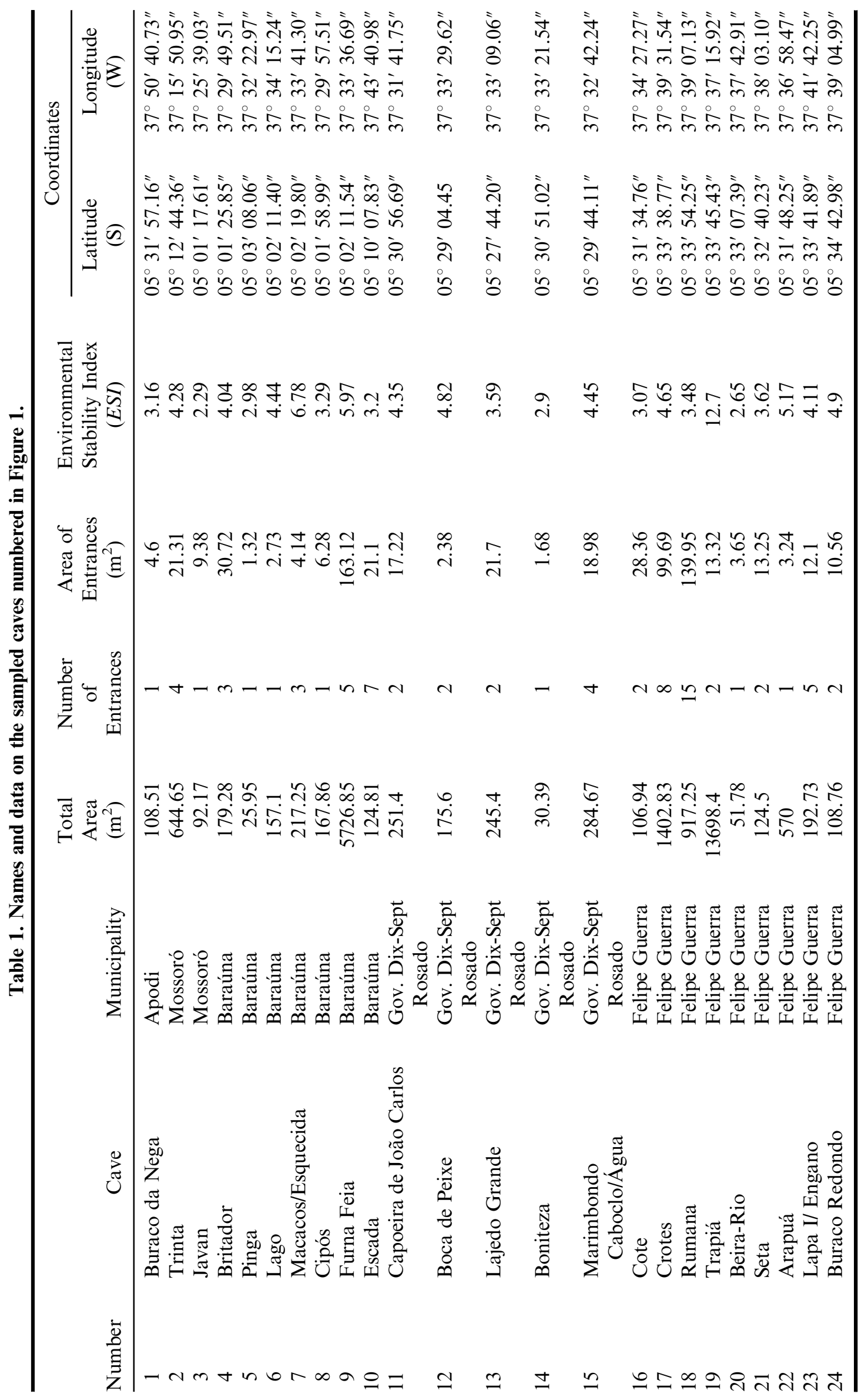




\section{RESUltS}

The invertebrate communities showed differences in their structure according to the collection season, with the greatest values of richness, abundance, and diversity index occurring during the rainy season (Tables 2 and 3). A total of 24,177 invertebrates were recorded. During the dry season, 9,275 individuals of 225 morphospecies belonging to 32 orders and 104 families were recorded. Collembola was the most abundant group, with 3,509 individuals (37.83 $\%$ ), followed by Araneae (969 individuals; $10.44 \%$ ) and Ensifera (754 individuals; $8.13 \%$ ). In the rainy season, 14,902 individuals of 302 morphospecies were found, belonging to 38 orders and 130 families. Again, Collembola was the most abundant group with 4,314 individuals (28.95 $\%$ ), followed by Araneae with 2,255 individuals (15.13\%), and Ensifera (1,300 individuals; $8.72 \%$ ) (Table 2).

Only eight orders showed a decrease in abundance during the rainy season (Opiliones, Scorpiones, Polydesmida, Spirobolida, Diptera, Embioptera, Isoptera, and Neuroptera). Five taxa were not found in the dry season (Scolopendromorpha, Symphyla, Diplura, Odonata and Turbellaria), and only one order was not found in the rainy season (Embioptera) (Table 2).

The average richness observed in the dry season was $27.62 \pm 12.1$ morphospecies per cave and in the rainy season $40.8 \pm 14.3$ morphospecies, while the average abundances were $386.46 \pm 368.46$ individuals in the dry season and $620.92 \pm 538.66$ individuals in the rainy season. For the diversity index, the values were $2.08 \pm 0.56$ in the dry season and $2.51 \pm 0.42$ in the rainy season. Stated uncertainties are standard errors; see Figure 2. All community parameters measured for the invertebrates of caves (morphospecies richness [ $t=-3.83$; df.46, $p<0.01]$, abundance $[t=-2.19 ;$ df.46, $p<0.05]$ and diversity index $[t=-2.99$; df.46, $p<0.01]$ ) were significantly higher during the rainy season (Table 3; Fig. 2).

The similarity calculated from presence and absence data among communities during the rainy and dry seasons was positively and significantly related to the $E S I$ of each cave $(R=0.45 ; p<0.05)$ (Fig. 3$)$.

\section{Discussion}

There is a clear relation between rainfall and the dynamics of invertebrate communities in epigean ecosystems in Caatinga, where the abundance and richness of taxa of soil macrofauna, especially of organisms related to the scavengers chain, increase considerably during the rainy season (Araújo et al., 2010b). Likewise, Vasconcellos et al. (2010) observed that ten of twelve insect orders have greater abundance or breeding and foraging activity at the time of increases in precipitation and relative humidity in Caatinga. Araújo et al. (2010a) reported that about $84 \%$ of collected scorpions were obtained in the rainy months, with precipitation and evapotranspiration as the variables most strongly related to the number of collected individuals.

Regarding the effects of seasonality in a cave, Lavoie et al. (2007) reported results similar to those found in the present work, regarding seasonal variations on the populations and the reproductive activity of cave crickets in North America, which affected populations of predators of their eggs, such as cave beetles (Kane and Poulson, 1976). Ferreira et al. (2005) also mentioned the greater availability of prey during the rainy season as the probable cause of the growth of Loxosceles similis population at Gruta da Lavoura, Minas Gerais, Brazil.

The majority of invertebrates found in Brazilian caves (Ferreira et al., 2010) are in troglophilic groups typically associated with soil and adjacent epigean habitats (Pintoda-Rocha, 1995; Trajano and Bichuette, 2009), including those from caves in the present work (Ferreira et al., 2010). Thus the patterns observed for epigean communities may be, to some extent, similar to those observed for subterranean communities.

One of the possible explanations for this fact is the almost complete dependence of organic resources importation from the surface, which makes relative changes in the communities of cave invertebrates something expected $(\mathrm{Cul}-$ ver and White, 2005). The increases in morphospecies richness, abundance, and diversity index in the rainy season demonstrate the association between hypogean and epigean ecosystems in the Caatinga, as rainfall causes an increased production of leaves, flowers and fruits, which is reversed in the dry season when there are few plant species producing flowers and leaves (Machado et al., 1997). This increase in organic resources supply for many invertebrates during the rainy season, especially for the herbivores, stimulates guilds of predators (Vasconcellos et al., 2010).

Although forests in limestone areas have well-defined phenophases and produce more leaf litter during dry periods (Brina, 1998), limestone caves tend to experience a greater transport of debris into the hypogean environment during the rainy season (Souza-Silva et al., 2007; Souza-Silva et al., 2011a). Rivers, streams, runoff, and percolation water can carry large amounts of organic matter such as leaves, tree fragments, animal carcasses, and dissolved organic compounds (Gibert et al., 1997; Simon et al., 2007; Souza-Silva et al., 2012).

Except for three caves (Trapiá, Furna Feia, and Lago), the others in the study area have no significant streams even during the rainy season, and even those with streams are not currently subject to flood events. Thus, flooding causing major changes in the invertebrate cave community or nutrient inflow, as reported by Souza Silva et al. (2011a) and Simões et al. (2015), is not expected.

The water from surface runoff and percolation seems to have a considerable influence on the organic resource supply in the studied region (Ferreira et al., 2010). During rainy periods the water enters through skylights and horizontal entrances, carrying organic matter, especially leaves 
Table 2. Abundance (N) and relative frequency (\%) of different invertebrate taxa sampled from all the studied caves in different seasons.

\begin{tabular}{|c|c|c|c|c|c|c|}
\hline \multirow[b]{2}{*}{ Invertebrate Taxa } & \multicolumn{2}{|c|}{ Dry Season } & \multicolumn{2}{|c|}{ Wet Season } & \multicolumn{2}{|c|}{ Total } \\
\hline & $\mathrm{N}$ & $\%$ & $\mathrm{~N}$ & $\%$ & $\mathrm{~N}$ & $\%$ \\
\hline Arthropoda & 9094 & 98.05 & 14646 & 98.28 & 23740 & 98.19 \\
\hline Chelicerata & 1710 & 18.44 & 3625 & 24.33 & 5335 & 22.07 \\
\hline Arachnida & 1710 & 18.44 & 3625 & 24.33 & 5335 & 22.07 \\
\hline Acari & 132 & 1.42 & 521 & 3.5 & 653 & 2.70 \\
\hline Amblypygi & 135 & 1.46 & 268 & 1.80 & 403 & 1.67 \\
\hline Araneae & 969 & 10.45 & 2255 & 15.13 & 3224 & 13.33 \\
\hline Opiliones & 126 & 1.36 & 113 & 0.76 & 239 & 0.99 \\
\hline Palpigradi & 1 & 0.01 & 10 & 0.07 & 11 & 0.05 \\
\hline Pseudoscorpiones & 48 & 0.52 & 72 & 0.48 & 120 & 0.50 \\
\hline Schizomida & 291 & 3.14 & 381 & 2.56 & 672 & 2.78 \\
\hline Scorpiones & 8 & 0.09 & 5 & 0.03 & 13 & 0.05 \\
\hline Myriapoda & 132 & 1.42 & 183 & 1.23 & 315 & 1.30 \\
\hline Diplopoda & 127 & 1.37 & 158 & 1.06 & 285 & 1.18 \\
\hline Polydesmida & 60 & 0.65 & 51 & 0.34 & 111 & 0.46 \\
\hline Polyxenida & 3 & 0.03 & 19 & 0.13 & 22 & 0.09 \\
\hline Spirobolida & 9 & 0.10 & 5 & 0.03 & 14 & 0.06 \\
\hline Spirostreptida & 55 & 0.59 & 83 & 0.56 & 138 & 0.57 \\
\hline Chilopoda & 5 & 0.05 & 20 & 0.13 & 25 & 0.10 \\
\hline Geophilomorpha & 2 & 0.02 & 6 & 0.04 & 8 & 0.03 \\
\hline Scolopendromorpha & 0 & * & 5 & 0.03 & 5 & 0.02 \\
\hline Scutigeromorpha & 3 & 0.03 & 9 & 0.06 & 12 & 0.05 \\
\hline Symphyla & 0 & $*$ & 5 & 0.09 & 5 & 0.07 \\
\hline Crustacea & 484 & 5.22 & 1112 & 7.46 & 1596 & 6.60 \\
\hline Amphipoda & 5 & 0.05 & 42 & 0.28 & 47 & 0.19 \\
\hline Isopoda & 479 & 5.16 & 1070 & 7.18 & 1549 & 5.41 \\
\hline Hexapoda & 6768 & 72.97 & 9276 & 65.27 & 16494 & 68.22 \\
\hline Entognatha & 3509 & 37.83 & 4318 & 28.98 & 7827 & 32.37 \\
\hline Collembola & 3509 & 37.83 & 4314 & 28.95 & 7823 & 32.36 \\
\hline Diplura & 0 & * & 4 & 0.03 & 4 & 0.02 \\
\hline Insecta & 3259 & 35.14 & 5408 & 36.29 & 8667 & 35.85 \\
\hline Archaeognatha & 2 & 0.02 & 9 & 0.06 & 11 & 0.05 \\
\hline Blattodea & 150 & 1.62 & 406 & 2.72 & 556 & 2.30 \\
\hline Coleoptera & 145 & 1.56 & 204 & 1.37 & 349 & 1.44 \\
\hline Diptera & 931 & 10.04 & 661 & 4.44 & 1592 & 6.58 \\
\hline Embioptera & 5 & 0.05 & 0 & * & 5 & 0.02 \\
\hline Ensifera & 754 & 8.13 & 1300 & 8.72 & 2054 & 8.50 \\
\hline Hemiptera & 223 & 2.40 & 367 & 2.46 & 590 & 2.44 \\
\hline Hymenoptera & 515 & 5.55 & 887 & 5.95 & 1402 & 5.80 \\
\hline Isoptera & 26 & 0.28 & 18 & 0.12 & 44 & 0.18 \\
\hline Lepidoptera & 264 & 2.85 & 391 & 2.62 & 655 & 2.71 \\
\hline Neuroptera & 51 & 0.55 & 31 & 0.21 & 82 & 0.34 \\
\hline Odonata & 0 & $*$ & 1 & 0.01 & 1 & $*$ \\
\hline Psocoptera & 141 & 1.52 & 893 & 5.99 & 1034 & 4.28 \\
\hline Zygentoma & 52 & 0.56 & 240 & 1.61 & 292 & 1.21 \\
\hline Annelida & 89 & 0.96 & 94 & 0.63 & 183 & 0.76 \\
\hline Oligochaeta & 89 & 0.96 & 94 & 0.96 & 183 & 0.76 \\
\hline Platyhelminthes & 0 & $*$ & 19 & 0.13 & 19 & 0.08 \\
\hline Turbellaria & 0 & $*$ & 19 & 0.13 & 19 & 0.08 \\
\hline Mollusca & 92 & 0.99 & 143 & 0.96 & 235 & 0.97 \\
\hline Gastropoda & 92 & 0.99 & 143 & 0.96 & 235 & 0.97 \\
\hline Total & 9275 & 100 & 14902 & 100 & 24177 & 100 \\
\hline
\end{tabular}

* means that the frequency was less than $0.1 \%$. 
Table 3. Community parameters $(\mathrm{S}$, morphospecies richness; $\mathrm{N}$, abundance; $\mathrm{H}^{\prime}$, Shannon diversity index) for each cave in different seasons.

\begin{tabular}{|c|c|c|c|c|c|c|}
\hline \multirow[b]{2}{*}{ Cave } & \multicolumn{3}{|c|}{ Dry Season } & \multicolumn{3}{|c|}{ Wet Season } \\
\hline & $\mathrm{S}$ & $\mathrm{N}$ & $\mathrm{H}^{\prime}$ & $\mathrm{S}$ & $\mathrm{N}$ & $\mathrm{H}^{\prime}$ \\
\hline Buraco da Nega & 26 & 99 & 2.72 & 32 & 324 & 2.68 \\
\hline Caverna do Trinta & 27 & 259 & 2.14 & 49 & 1235 & 2.33 \\
\hline Caverna de Javan & 14 & 152 & 1.81 & 39 & 302 & 2.54 \\
\hline Caverna do Britador & 21 & 211 & 2.36 & 50 & 393 & 2.49 \\
\hline Gruta do Pinga & 13 & 443 & 0.76 & 31 & 382 & 2.15 \\
\hline Caverna do Lago & 21 & 353 & 1.97 & 33 & 706 & 1.58 \\
\hline \multicolumn{7}{|l|}{ Cav.Macacos/ } \\
\hline Esquecida & 36 & 230 & 2.75 & 42 & 269 & 3.02 \\
\hline Caverna dos Cipós & 17 & 178 & 1.59 & 38 & 280 & 2.64 \\
\hline Furna Feia & 61 & 1895 & 2.40 & 57 & 2497 & 2.47 \\
\hline Gruta da Escada & 25 & 209 & 2.84 & 39 & 236 & 2.89 \\
\hline \multicolumn{7}{|l|}{ Cav. Capoeira de João } \\
\hline Carlos & 26 & 559 & 1.51 & 69 & 992 & 2.47 \\
\hline Gruta Boca de Peixe & 13 & 59 & 2.22 & 42 & 445 & 2.91 \\
\hline \multicolumn{7}{|l|}{ Caverna do Lajedo } \\
\hline Grande & 17 & 79 & 2.52 & 37 & 557 & 2.31 \\
\hline Caverna da Boniteza & 26 & 260 & 2.15 & 35 & 404 & 2.21 \\
\hline \multicolumn{7}{|l|}{ Cav. Marimbondo } \\
\hline Caboclo/Água & 36 & 613 & 2.27 & 66 & 580 & 3.43 \\
\hline Caverna do Cote & 16 & 239 & 1.98 & 24 & 357 & 2.29 \\
\hline Caverna dos Crotes & 50 & 632 & 2.49 & 77 & 742 & 3.06 \\
\hline Caverna da Rumana & 49 & 331 & 3.03 & 39 & 473 & 2.86 \\
\hline Caverna do Trapiá & 27 & 571 & 1.51 & 36 & 1579 & 2.56 \\
\hline Caverna Beira-Rio & 33 & 591 & 1.04 & 33 & 151 & 2.80 \\
\hline Caverna da Seta & 29 & 165 & 2.44 & 17 & 177 & 2.02 \\
\hline Caverna do Arapuá & 31 & 520 & 1.64 & 34 & 972 & 1.85 \\
\hline \multicolumn{7}{|l|}{ Lapa I/ Caverna do } \\
\hline Engano & 23 & 211 & 2.07 & 37 & 755 & 2.03 \\
\hline \multicolumn{7}{|l|}{ Caverna do Buraco } \\
\hline Redondo & 26 & 416 & 1.79 & 24 & 94 & 2.66 \\
\hline
\end{tabular}

and branches, into the caves. So in addition to resources such as carcasses and guano provided to the cave fauna by trogloxenes, other agents, such as water, play an important role during the rainy season (Ferreira et al., 2010).

Regarding the organic matter carried by trogloxenes, bat guano plays an important role as a food source for many communities inside the studied caves. Since most of them do not have perennial water, guano becomes one of the main resources available the entire year (Ferreira et al., 2010), and several studies have shown the importance of guano as a source of organic matter for cave communities, especially in permanently dry caves (Ferreira and Martins, 1998; Ferreira and Martins, 1999; Ferreira et al., 2000; Ferreira et al., 2007; Pellegrini and Ferreira, 2013; Pape, 2014; Iskali and Zhang, 2015). Furthermore, in a similar way to what occurs in temperate regions where bat colonies often exhibit annual cycles and add a temporal component to the deposition of guano (Harris, 1970), most species of Neotropical bats tend to synchronize their reproductive periods with periods of increased food availability, which usually occurs during the rainy season (Willig, 1985; Bernard, 2002). This situation leads to a similar cycle in the abundance of invertebrates that depend directly or indirectly on guano.

Another factor contributing to the increase in activity or abundance of invertebrates during the rainy season may be the direct and indirect consequences of rain on decomposition and the invertebrate populations involved in this process. Soil moisture is a key factor for the increase in biomass of edaphic microorganisms, stimulating species of scavenger arthropods and predators that are part of soil micro-, meso-, and macrofauna (Swift et al., 1979, Lavelle et al., 1995). In terrestrial environments of caves, unfavorable conditions such as low humidity may inhibit colonization by animals and decrease the rate of plant debris processing (Souza-Silva et al., 2011a), since high humidity is critical to rapid decomposition because it regulates the metabolism of the decomposer organisms (Souza-Silva et al., 2013).

Therefore, fluctuations in morphospecies richness and abundance during the rainy season are certainly related to variations of the main routes of matter and energy into the caves. Although the details were not assessed directly in this work, they must be related to a greater transport of organic material, especially of vegetable origin, from the surface by rains, increased deposition of guano, and the increase in the rate of decomposition of animal and especially vegetable organic matter in caves.

A significant relationship between the similarity of invertebrate communities in the dry and rainy seasons and the Environmental Stability Index of each cave certainly reflects an interaction between hypogean and epigean ecosystems. However, the degree of interaction between these two systems was not uniform, and the most isolated caves exhibited little variation in the invertebrate fauna between seasons, a consequence of a low interaction with the epigean ecosystem (Poulson and White, 1969; Culver, 1982; Howarth, 1983). This trend indicates that caves with greater ESI and more stability tend to maintain the structure of their communities in comparison with less stable caves.

Caves and other subterranean habitats are not fully stable environments as is often assumed, but they exhibit seasonal fluctuations in temperature and humidity that reflect a delayed response to the climate change on the surface (Tobin et al., 2013). In most of the caves, the seasonality on the surface affects the speed, direction, and daily fluctuations in pressure and chimney effect on air flows, resulting in seasonal variations of moisture and temperature (Howarth, 1980; Cigna, 2002). Variable environmental conditions tend to occur in areas next to the entrances, while the most stable 

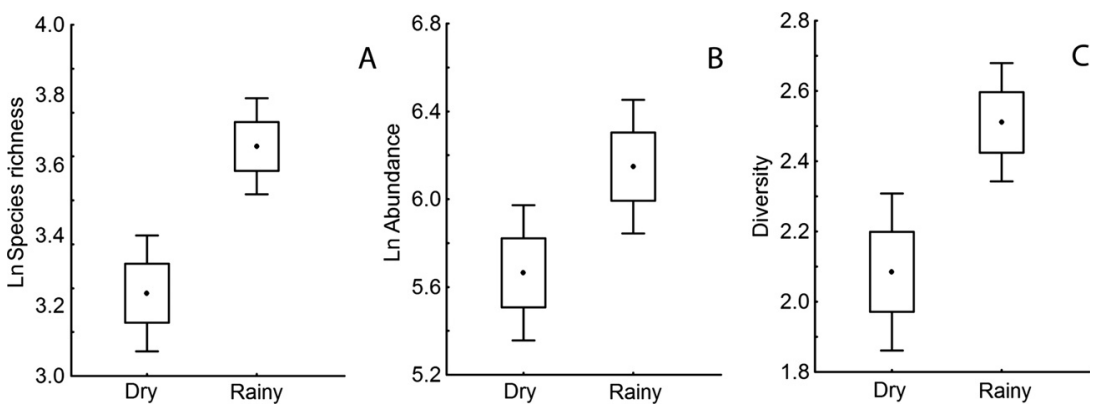

Figure 2. Community parameters of sampled cave invertebrate communities during dry and rainy seasons: a. morphospecies richness (log values); b. abundance (log values); c. Shannon diversity index. Central dots inside box-plots represent mean values, boxes represent standard errors, and bars represent standard deviation.

conditions occur in deeper areas within the caves (Tobin et al., 2013).

As a result, the classical interpretation leads one to expect that trogloxenes are more suited to the entrance zone, troglophiles in the twilight zone, and troglobionts in the totally dark zone, deep inside the cave (Novak et al., 2012). Thus, although this work did not attempt an ecological classification of the sampled groups, which would require more detailed ecological studies, the results suggest some considerations.

Generally, species that are more specialized to the cave environment tend to be restricted to the aphotic areas with more stable temperature and humidity. Troglobiont and troglophile species are commonly stenothermic (adapted to a narrow temperature range) and stenohygrobic (Barr and
Kuehne, 1971; Howarth, 1980). Such preferences are probably generated by the presence of thinner exoskeletons and longer appendages, resulting in greater desiccation in relation to surface taxa (Howarth, 1980). Thus, their distribution can be influenced by seasonal changes in temperature and humidity, and, in many cases, such species are restricted to areas with more stable temperature and humidity (Tobin et al., 2013). For these groups, the entrance zone acts as a disturbance, disrupting or limiting their preferred subsurface habitat that range from the shallow subterranean to deep caves (Novak et al., 2012). Such species tend to form communities with stable composition and distribution over time and space.

The entrance and transition twilight areas, in turn, have microhabitats that vary considerably according to changes

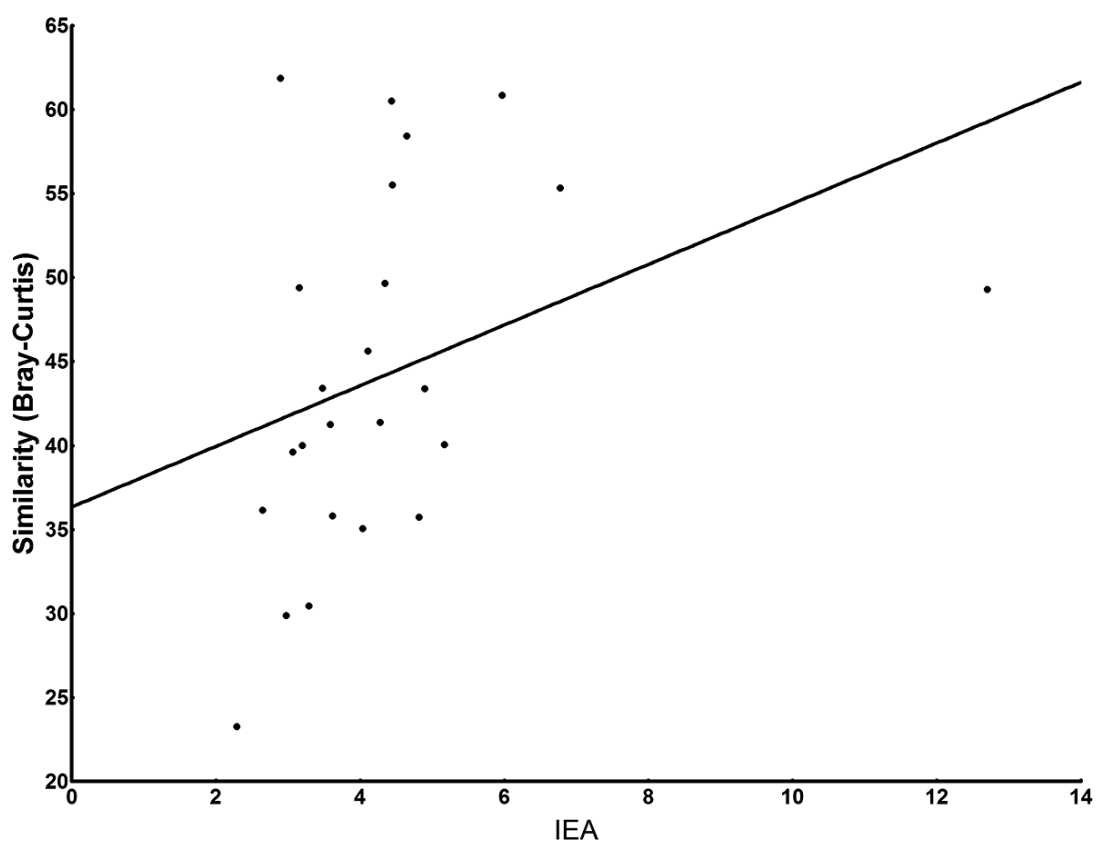

Figure 3. Positive and significant correlation $(R=0.45 ; p<0.05)$ between the similarity (Bray-Curtis) of invertebrate communities in the dry and wet seasons in the same cave and its Environmental Stability Index (IEA, from Portuguese initials). 
in the external environment (Culver, 1982). These habitats are subject to colonization by a wide range of invertebrate species, with or without pre-adaptation to the deep hypogean environments (Ferreira and Martins, 2001; Prous et al., 2004) and generally exhibit a greater species diversity than deep subterranean habitats (Culver and Pipan, 2009). Thus, these communities have much more temporally variable composition.

\section{Conclusions}

Morphospecies richness, abundance, and diversity index in caves were significantly higher during the rainy season. There was a difference in the community structure between seasons, showing a clear relationship between hypogean and epigean environments. Nevertheless, this relationship may vary according to the environmental stability of the hypogean ecosystem; greater internal stability will lead to a lower fluctuation in the composition of the invertebrate community throughout the year. Moreover, these seasonal differences in the invertebrate fauna reinforce the need for biological samples during at least two different seasons as required in the current Brazilian environmental legislation dealing with the environmental licensing of projects and activities potentially harmful to caves (MMA, 2009).

Climate change projections for Latin America indicate a slight increase in temperature and increased variability in rainfall for the next decades (Silva, 2004; Sivakumar et al., 2005). For Caatinga, both drastic decreases and significant increases in precipitation are plausible scenarios for the next 50 years (Krol and Bronstert, 2007). According to our results, these climatic changes will probably have effects on cave communities and their directly or indirectly associated ecosystems. Partial loss of biodiversity in these systems would be important not only in a local ecological context, but also because several collected species are undescribed, and probably many of them have distribution restricted to the sampled region.

\section{ACKNOWLEDGEMENTS}

The authors would like to thank Programa de Pós-Graduação em Ciências Biológicas (UFRN), Laboratório de Ecologia e Conservação da Biodiversidade (LECB/ UFRN), Centro de Estudos em Biologia Subterrânea (CEBS/UFLA), and Centro Nacional de Pesquisa e Conservação de Cavernas (ICMBio/CECAV) for providing infrastructure for the development of the study. Thanks to Darcy Santos, Iatagan Freitas, Uilson Campos, and Geilson Goes for helping with the collections; to colleagues of CEBS/UFLA and LECB/UFRN for helping with the material analysis and invertebrate identification; and to Dr. Mauro Pichorim for valuable contributions to the text. Funding was provided by the Conselho Nacional de
Pesquisa (CNPq), process n. 477712/2006-1, and to R.L.F. (CNPq grant n. 304682/2014-4).

\section{REFERENCES}

Aguiar, C.M.L., and Martins, C.F., 1997, Abundância relativa, diversidade e fenologia de abelhas (Hymenoptera, Apoidea) na Caatinga, São João do Cariri, Paraíba, Brasil: Iheringi, Série Zoologia, v. 83, p. $151-163$.

Araújo, C.S, Candido, D.M, Araújo, H.F.P, Dias, S.C, Vasconcellos, A., 2010a, Seasonal variations in scorpion activities (Arachnida: Scorpiones) in an area of Caatinga vegetation in northeastern Brazil: Zoologia, v. 27, no. 3, p. 372-376. doi:10.1590/S1984-46702010000300008.

Araújo, V.F.P, Bandeira, A.G, Vasconcellos, A., 2010b, Abundance and stratification of soil macroarthropods in a Caatinga Forest in Northeast Brazil: Brazilian Journal of Biology, v. 70, no. 3 suppl., p. 737-746. doi:10.1590/S1519-69842010000400006.

Barr, T.C. and Kuehne, R.A., 1971, Ecological studies in the Mammoth Cave system of Kentucky II: the ecosystem: Annales de Spéléologie, v. 26 , p. $47-96$.

Bernard, E., 2002, Diet, activity and reproduction of bat species (Mammalia, Chiroptera) in Central Amazonia, Brazil: Revista Brasileira de Zoologia, v. 19, no. 1, p. 173-188. doi:10.1590/S0101-81752002000100016.

Bezerra, F.H.R., Takeya, M.K., Sousa, M.O.L., Nascimento, A.F., 2007, Coseismic reactivation of the Samambaia fault, Brazil. Tectonophysics, v. 430, p. 27-39. doi:10.1016/j.tecto.2006.10.007.

Brina, A.E., 1998, Aspectos da dinâmica da vegetação associada a afloramentos calcários na APA Carste de Lagoa Santa, MG [Masters Thesis]: Belo Horizonte, Universidade Federal de Minas Gerais, 105 p.

Cigna, A.A, 2002, Modern trend in cave monitoring: Acta Carsologica, v. 31, p. $35-54$

Clarke, K.R., and Warwick, R.M., 2001, Change in Marine Communities: An Approach to Statistical Analyses and Interpretation 2nd edition: Plymouth, United Kingdom, PRIMER-E Ltd, 176 p.

Culver, D.C, 1982, Cave Life. Evolution and Ecology: Cambridge, Harvard University Press.

Culver, D.C., and Pipan, T., 2009, The Biology of Caves and Other Subterranean Habitats: New York, Oxford University Press, 256 p.

Culver, D.C., and White, W.B., 2005, Encyclopedia of Caves: Amsterdam, Academic/Elsevier Press, $654 \mathrm{p}$.

Day, A., 2002, Cave Surveying: Buxton: British Cave Research Association, Cave Studies Series 11, $40 \mathrm{p}$.

Derraik, J.G.B., Closs, G.P., Dickinson, K.J.M., Sirvid, P., Barratt, B.I.P., and Patrick, B.H, 2002, Arthropod morphospecies versus taxonomic species: a case study with Araneae, Coleoptera, and Lepidoptera: Conservation Biology, v. 16, p. 1015-1023. doi:10.1046/j.1523-1739.2002. $00358 \mathrm{x}$.

Derraik, J.G.B., Early, J.W., Closs, G.P., and Dickinson, K.J.M., 2010, Morphospecies and taxonomic species comparison for Hymenoptera: Journal of Insect Science. v. 10, article 108, 7 p. doi: 10.1673/031.010. 10801.

Ducarme, X., André, H.M., Wauthy, G., and Lebrun, P., 2004, Comparison of endogeic and cave communities: microarthropod density and mite species richness: European Journal of Soil Biology, v. 40, no. 3-4, p. 129-138. doi:10.1016/j.ejsobi.2004.10.003.

Ferreira, R.L., 2004, A medida da complexidade ecológica e suas aplicações na conservação e manejo de ecossistemas subterrâneos [Ph.D. thesis]: Belo Horizonte, Universidade Federal de Minas Gerais, 161 p. [http://pos.icb.ufmg.br/pgecologia/teses/T23_rodrigo_lopes $\% 20$. pdf]

Ferreira, R.L., and Martins, R.P., 1998, Diversity and distribution of spiders associated with bat guano piles in Morrinho cave (Bahia State, Brazil): Diversity and Distributions, v. 4, no. 5-6, p. 235-241.

Ferreira, R.L., and Martins, R.P., 1999, Trophic structure and natural history of bat guano invertebrate communities, with special reference to Brazilian caves: Tropical Zoology, v. 12, no. 2, p. 231-252. doi:10. 1080/03946975.1999.10539391.

Ferreira, R.L., and Martins, R.P., 2001, Cavernas em risco de 'extinção': Ciência Hoje, v. 29 , no. 173 , p. 20-28.

Ferreira, R.L., Martins, R.P., and Yanega, D., 2000, Ecology of bat guano arthropod communities in a Brazilian dry cave: Ecotropica, v. 6, no. 2, p. $105-116$. 
Ferreira, R.L., Prous, X., Machado, S.F., and Martins, R.P., 2005, Population dynamics of Loxosceles similis (Moenkhaus, 1898) in a brazilian dry cave: a new method for evaluation of population size: Revista Brasileira de Zoociências, v. 7, p. 129-141.

Ferreira, R.L., Prous, X., and Martins, R.P., 2007, Structure of bat guano communities in a dry Brazilian cave: Tropical Zoology, v. 20, p. 55-74

Ferreira, R.L, Prous, X., Bernardi, L.F.O., Souza-Silva, M., 2010, Fauna subterrânea do Estado do Rio Grande do Norte: Caracterização e impactos: Revista Brasileira de Espeleologia, v. 1, p. 25-51.

Gibert, J., Mathieu, J., and Fournier F., eds., 1997, Groundwater/ Surface water ecotones: Biological and hydrological interactions and management options: Cambridge, UK, Cambridge University Press, International Hydrobiology Series, Cambridge, 246 p. doi:10.1017/ CBO9780511753381.

Gusmão, M.A.B., and Creão-Duarte, A.J., 2004, Diversidade e análise faunística de Sphingidae (Lepidoptera) em área de brejo e caatinga no Estado da Paraíba, Brasil: Revista Brasileira de Zoologia, v. 21, p. 491-498. doi:10.1590/S0101-81752004000300011.

Harris, J.A., 1970, Bat guano cave environment: Science, v. 169, p. 1342-1343. doi:10.1126/science.169.3952.1342-a.

Hernández, M.I.M., 2007, Besouros escarabeíneos (Coleoptera: Scarabaeidae) da caatinga paraibana, Brasil: Oecologia Brasiliensis, v. 11, p. 356-364.

Howarth, F.G., 1980, The zoogeography of specialized cave animals: a bioclimatic model: Evolution, v. 34, p. 394-406. doi:10.2307/2407402.

Howarth, F.G., 1983, Ecology of cave arthropods: Annual Review of Entomology, v. 28, p. 365-389. doi:10.1146/annurev.en.28.010183.002053.

Iannuzzi, L., Maia, A.C.D, Vasconcelos, S.D., 2006, Ocorrência e sazonalidade de coleópteros buprestídeos em uma região de caatinga nordestina: Biociências, v. 14, p. 174-179.

IDEMA, Instituto de Desenvolvinmento Sustentável e Meio Ambiente, 2005, Atlas para o Desenvolvimento Sustentável do RN, www.idema. rn.gov.br/governo/secretarias/idema/atlasdes/atlas.zip, [acessed February 10,2014$]$.

INPE, Instituto Nacional de Pesquisas Espaciais, 2010, Balanço Hídrico Municipal, www.cptec.inpe.br/proclima, [accessed on February 12, 2014].

Iskali, G., and Zhang, Y., 2015, Guano subsidy and the invertebrate community in Bracken Cave: the world's largest colony of bats: Journal of Cave and Karst Studies, v. 77, no. 1, p. 28-36. doi:10.4311/ 2013 LSC0128.

Kane, T.C., and Poulson, T.L., 1976, Foraging by cave beetles: Spatial and temporal heterogeneity of prey: Ecology, v. 57, p. 793-800. doi:10.2307/ 1936192.

Kottek, M., Grieser, J., Beck, C., Rudolf, B., and Rubel, F., 2006, World map of the Köppen-Geiger climate classification updated: Meteorologische Zeitschrift, v. 15, no. 3, p. 259-263. doi:10.1127/0941-2948/2006/ 0130.

Krol, M.S., and Bronstert, A., 2007, Regional integrated modelling of climate change impacts on natural resources and resource usage in semiarid Northeast Brazil: Environmental Modelling \& Software, v. 22, p. 259-268. doi:10.1016/j.envsoft.2005.07.022.

Lavelle, P., Lattaud, D.T., and Barois, I., 1995, Mutualism and biodiversity in soils: Plant and Soil, v. 170, p. 23-33. doi:10.1007/BF02183052.

Lavoie, K.H., Helf, K.L, and Poulson, T.L., 2007, The biology and ecology of North American cave crickets: Journal of Cave and Karst Studies, v. 69 , p. $114-134$.

Machado, I.C.S., Barros, L.M., and Sampaio, E.V.S.B., 1997, Phenology of caatinga species at Serra Talhada, PE, Northeastern Brazil: Biotropica, v. 29 , p. $57-68$.

Magurran, A.E., 1988, Ecological Diversity and Its Measurement: London, Cromm Helm, $179 \mathrm{p}$.

Medeiros, J., Araújo, A., Araújo, H.F.P., Queiroz, J.P.C., and Vasconcellos, A., 2012, Seasonal activity of Dinoponera quadriceps Santschi (Formicidae, Ponerinae) in the semi-arid Caatinga of northeastern Brazil: Revista Brasileira de Entomologia, v. 56, no. 1, p. 81-85. doi:10.1590/S0085-56262012000100013.

MMA, Ministério de Meio Ambiente, 2009, Instrução Normativa $\mathrm{N}^{\circ} 02$, de 20 de agosto de 2009. Diário Oficial da República Federativa do Brasil, Brasil.

Novak, T., Perc, M., Lipovšek, S., and Janžekovič, F., 2012, Duality of terrestrial subterranean fauna: International Journal of Speleology, v. 41, no. 2, p. 181-188. doi:10.5038/1827-806X.41.2.5.

Oliver, I., and Beattie, A.J., 1996a, Invertebrate morphospecies as surrogates for species: a case study: Conservation Biology, v. 1, no. 10, p. 99-109. doi:10.1046/j.1523-1739.1996.10010099.x.
Oliver, I., and Beattie, A.J., 1996b, Designing a cost-effective invertebrate survey: a test of methods for rapid assessment of biodiversity: Ecological Applications, v. 6, no. 2, p. 594-607. doi:10.2307/2269394.

Pape, R.B., 2014, Biology and ecology of Bat Cave, Grand Canyon National Park, Arizona: Journal of Cave and Karst Studies, v. 76, no. 1, p. 1-13. doi:10.4311/2012LSC0266.

Pellegrini, T.G., and Ferreira, R.L., 2013, Structure and interactions in a cave guano-soil continuum community: European Journal of Soil Biology, v. 57, p. 19-26. doi:10.1016/j.ejsobi.2013.03.003.

Pinto-da-Rocha, R., 1995, Sinopse da fauna cavernícola do Brasil (19071994): Papéis Avulsos de Zoologia, v. 39, no. 6, p. 61-173.

Poulson, T.L., and White, W.B., 1969, The cave environment: Science, v. 165, p. 971-981. doi:10.1126/science.165.3897.971.

Prous, X., Ferreira, R.L., and Martins, R.P., 2004, Ecotone delimitation: epigean-hypogean transition in cave ecosystems: Austral Ecology, v. 29, p. 374-382. doi:10.1111/j.1442-9993.2004.01373.x.

Sampaio, E.V.S.B., 1995, Overview of the Brazilian caatinga, in Bullock, S.H., Mooney, H.A., and Medina, E., eds., Seasonally Dry Tropical Forests: Cambridge, Cambridge University Press, p. 35-58. doi: 10.1017/CBO9780511753398.003.

Schneider, K., Christman, M.C., and Fagan, W.F., 2011, The influence of resource subsidies on cave invertebrates: results from an ecosystemlevel manipulation experiment: Ecology, v. 92, no. 3, p. 765-776. doi:10.1890/10-0157.1.

Sharratt, N.J., Picker, M.D., and Samways, M.J., 2000, The invertebrate fauna of the sandstone of the caves of the Cape Penisula (South Africa): patterns of endemism and conservation priorities: Biodiversity and Conservation, v. 9, p. 107-143. doi:10.1023/A:1008968518058.

Silva, V.P.R., 2004, On climate variability in northeast of Brazil: Journal of Arid Environments, v. 58, p. 575-596. doi:10.1016/j.jaridenv.2003. 12.002 .

Simões, M.H., Souza-Silva, M., and Ferreira, R.L., 2015, Cave physical attributes influencing the structure of terrestrial invertebrate communities in Neotropics: Subterranean Biology 16: 103-121. doi:10.3897/ subtbiol.16.5470.

Simon, K.S., Pipan, T., and Culver, D.C., 2007, A conceptual model of the flow and distribution of organic carbon in caves: Journal of Cave and Karst Studies, v. 69, p. 279-284.

Sivakumar, M.V.K., Das, H.P., and Brunini, O., 2005, Impacts of present and future climate variability and change on agriculture and forestry in the arid and semi-arid tropics: Climatic Change, v. 70, p. 31-72. doi:10.1007/s10584-005-5937-9.

Souza-Silva, M., Ferreira, R.L., Bernardi, L.F.O., and Martins, R.P., 2007, Importação e processamento de detritos orgânicos em uma caverna calcária: Espeleo-Tema, v. 19, p. 31-46.

Souza-Silva, M., Martins, R.P., and Ferreira, R.L., 2011a, Trophic Dynamics in a Neotropical Limestone Cave: Subterranean Biology, v. 9, p. 127-138. doi:10.3897/subtbiol.9.2515.

Souza-Silva, M., Martins, R.P., and Ferreira, R.L., 2011b, Cave lithology determining the structure of the invertebrate communities in the Brazilian Atlantic Rain Forest: Biodiversity and Conservation, v. 20, no. 8, p. 1713-1729. doi:10.1007/s10531-011-0057-5.

Souza-Silva, M., Bernardi, L.F.O., Martins, R.P., and Ferreira, R.L., 2012, Transport and consumption of organic detritus in a neotropical limestone cave: Acta Carsologica, v. 41, no. 1, p. 139-150.

Souza-Silva, M., Júnior, A.S., and Ferreira, R.L., 2013, Food resource availability in a quartzite cave in the Brazilian montane Atlantic Forest: Journal of Cave and Karst Studies, v. 75, no. 3, p. 177-188. doi:10. 4311/2010JCKS0158.

Swift, M.J., Heal, O.W., and Anderson, J.M., 1979, Decomposition in Terrestrial Ecosystems: London, Blackwell Scientific, Studies in Ecology series, $372 \mathrm{p}$.

Tobin, B.W., Hutchins, B.T., and Schwartz, B.F., 2013, Spatial and temporal changes in invertebrate assemblage structure from the entrance to deep-cave zone of a temperate marble cave: International Journal of Speleology, v. 42, no. 3, p. 203-214. doi:10.5038/1827-806X. 42.3.4.

Trajano, E., 1987, Fauna cavernícola brasileira: composição e caracterização preliminar: Revista Brasileira de Zoologia, v. 3, no. 8, p. 533-561. doi:10.1590/S0101-81751986000400004.

Trajano, E., and Bichuette, M.E., 2009, Diversity of Brazilian subterranean invertebrates, with a list of troglomorphic taxa: Subterranean Biology, v. 7, p. 1-16. 
D. de M. Bento, R.L. Ferreira, X. Prous, M. Souza-Silva, B.C. Bellini, and A. Vasconcellos

Vasconcellos, A., Andreazze, R., Almeida, A.M., Araujo, H.F.P., Oliveira, E.S., and Oliveira, U., 2010, Seasonality of insects in the semi-arid Caatinga of northeastern Brazil: Revista Brasileira de Entomologia, v. 54, no. 3, p. 471-476. doi:10.1590/S0085-56262010000300019.

Ward, D.F., and Stanley, M.C., 2004, The value of RTUs and parataxonomy versus taxonomic species: New Zealand Entomologist: v. 27, p. 3-9. doi:10.1080/00779962.2004.9722118.
Weinstein, P., and Slaney, D., 1995, Invertebrate faunal survey of Rope Ladder Cave, Northern Queensland: a comparative study of sampling methods: Journal of the Australian Entomological Society, v. 34, p. 233-236. doi:10.1111/j.1440-6055.1995.tb01329.x.

Willig, M.R., 1985, Reproductive patterns of bats from caatingas and cerrado biomes in northeast Brazil: Journal of Mammalogy, v. 66, no. 4, p. 668-681. doi:10.2307/1380793. 